\title{
Andrzej A. Napiórkowski OSPPE Maryja jest piękna. Zarys mariologii \\ i maryjności \\ Uniwersytet Papieski Jana Pawła II w Krakowie, Wydawnictwo Naukowe, Kraków [2016], 280 s.
}

Autorem recenzowanej książki zatytułowanej: Maryja jest piękna. Zarys mariologii i maryjności, jest ojciec prof. dr hab. Andrzej Adam Napiórkowski, kapłan Zakonu Paulinów. Nieprzerwanie od marca 2001 roku kieruje Katedrą Eklezjologii na Wydziale Teologicznym Papieskiego Uniwersytetu Jana Pawła II w Krakowie. Ponadto w tymże Uniwersytecie pełni funkcję zastępcy dyrektora Instytutu Teologii Fundamentalnej, Ekumenii i Dialogu.

Jako teolog specjalizuje się zwłaszcza w eklezjologii integralnej (fundamentalnej i dogmatycznej). Jego badania naukowe dotycza szczególnie tematów z dziedziny eklezjologii i chrystologii, zagadnień ekumenicznych w szerokim ujęciu, dialogu katolicko-luterańskiego, problematyki wolności, łaski, usprawiedliwienia, oraz mariologii i tematyki pastoralnej i okolicznościowej.

Książka Maryja jest piękna to dojrzały owoc pełnej zapału, pasji i żmudnej pracy naukowej o. Andrzeja Napiórkowskiego. Odznacza się niewątpliwą wartością naukową i dydaktyczną. Myślę, że szybko znajdzie uznanie na rynku wydawniczym. Nieustannie będzie zyskiwała nowych czytelników. Jest starannie przygotowana i edytowana przez Wydawnictwo Naukowe Uniwersytetu Papieskiego Jana Pawła II w Krakowie. Było to możliwe dzięki finansowaniu z dotacji na 
Reports and reviews utrzymanie potencjału badawczego UPJP II przyznanej przez Ministra Nauki i Szkolnictwa Wyższego w 2016 roku. Na ostatniej stronie pięknej okładki zostały umieszczone słowa wstępu autorskiego i fragment recenzji wydawniczej, sporządzonej przez ks. dr. hab. Janusza Lekana, prof. KUL, dyrektora Instytutu Teologii Dogmatycznej KUL.

Przywołany recenzent podkreślił, że widocznym celem, jaki autor sobie stawia dla tej publikacji jest ,dostarczenie czytelnikowi wszystkich podstawowych i niezbędnych informacji dotyczących osoby Najświętszej Maryi Panny i jej miejsca w Bożym planie zbawienia”. Zaznacza też, że ,autor umiejscawia ją w kontekście, w jakim znajduje się współczesny czytelnik, zwracając uwagę zarówno na wyzwania powszechne, wynikające ze współczesnego feminizmu, jak również specyficzne dla polskiego czytelnika, uwypuklając kontekst polskiej mariologii. Wreszcie wskazuje na miejsce mariologii w całości historii rozwoju dogmatów katolickich, na jej specyfikę w ramach teologii dogmatycznej i jej podstawowe źródła”.

Książka Maryja jest piękna. Zarys mariologii $i$ maryjności, licząca 280 stron, została podzielona na dziewięć rozdziałów. Rozdział pierwszy nosi tytuł: Ku integralnej mariologii. Zawiera następujące paragrafy: Kim jest Maryja?, Kontekst wspótczesny, Historia rozwoju mariologii, Mariologia jako traktat dogmatyczny, Źródła mariologii. Rozdział drugi zatytułowany: Pismo Święte o Maryi, ukazuje miejsca Starego i Nowego Testamentu, które typicznie lub bezpośrednio zawierają odniesienia do Najświętszej Maryi Panny. Rozdział trzeci: Dzieje maryjnej teologii duchowości, koncentruje się na historii Maryjnej teologii duchowości, poczynając od pisarzy apostolskich i apologetów poprzez Ojców Kościoła, teologię średniowiecza, reformację, kulturę baroku, oświecenie, teologię XIX i XX wieku, Sobór Watykański II, by w finale nakreślić obecnie obierany kierunek ku mariologii integralnej i interdyscyplinarnej. W rozdziale czwartym: Maryjne prawdy, autor omawia pięć podstawowych prawd wiary dotyczących Maryi. Są to: Matka Boga, zawsze dziewica, wolna od grzechu i święta, Niepokalanie Poczęta, i Wniebowzięta.

Dużo nowych elementów mariologicznych przynosi rozdział piąty, ukazujący Jedność Maryi z Duchem Świętym, gdzie czytelnik może znaleźć takie zagadnienia, jak: „Maryja i Duch Święty”, „Jedność Maryi z Duchem Trójjedynego Boga" czy formy i sposoby jedności Maryi z Duchem Boga. Rozdział szósty: Maryja w dziele odkupienia, oprócz wielu pomniejszych zagadnień, zawiera rozwinięcie czterech podstawowych tematów: współdziałanie Maryi, pośrednictwo Maryi, macierzyństwo duchowe Maryi i relacja Maryja - Kościół. 
Rozdział siódmy: Celebracja Maryi w Kościele, podejmuje w swojej rozbudowanej treści szczególnie takie kwestie, jak: „,z dziejów maryjnej pobożności”, „dlaczego należy czcić Maryję?”, teologia kultu Maryjnego i jego odnowa w świetle Marialis cultus, liturgiczne miejsca i sposoby kultu Maryi, modlitewne formy czci Bogarodzicy, przepowiadanie o Matce Pana i jego formy, homilie, kazania, katechezy. Refleksji teologicznej poddane zostały także sprawy sanktuariów Maryjnych i pielgrzymowania, kultura i sztuka związana z kultem Maryi, ośrodki naukowe i centra formacji Maryjnej. Na końcu rozdziału zaprezentowano Polskie Towarzystwo Mariologiczne.

Rozdział przedostatni: Artyzm i transcendencja Maryjnych obrazów, zapoznaje czytelnika z artyzmem i transcendencją maryjnych obrazów. Ojciec Andrzej Napiórkowski podejmuje w nim aspekt piękna Maryi, problem rzekomego zakazu sporządzania ikon w Biblii, historię teologii ikony, temat Wcielenia jako chrystologicznego fundamentu Maryjnej ikony, oraz zagadnienie typów ikon Maryjnych. Natomiast ostatni rozdział to wizja mariologii ekumenicznej. Ojciec Profesor porusza w nim takie tematy, jak: Prawostawie i Przebtogostawiona, Ewangelicy a Matka Pana, Wspótczesny dialog chrześcijan oraz Ekumeniczne rozstaje i zbliżenia.

Czytając książkę, nietrudno zauważyć, że ukazuje ona wielkie bogactwo katolickiej nauki o Najświętszej Maryi Pannie. Ogromną wartością tej pozycji jest to, że autor nie poprzestaje tylko na odtwórczym prezentowaniu treści, jakie w opracowaniach naukowych już można znaleźć, lecz ukazuje własne przemyślenia co do wielkich perspektyw i możliwości mariologii. Niezwykle ważne jest to, że w swojej refleksji teologicznej mocno osadza maryjność i mariologię w Kościele, gdzie jak stwierdza: „Bosko-ludzka rzeczywistość gwarantuje tak duchowy, jak i intelektualny wymiar naszego poznania".

O niekwestionowanej wartości tej książki świadczy również wykorzystana w niej bogata, licząca ponad 200 pozycji bibliografia. Ponad 30 pozycji, to opracowania w językach obcych: niemieckim, włoskim i francuskim, a ponad 20 pozycji bibliograficznych, to wcześniejsze opracowania samego autora. Zatem książka nie jest wytworem chwili, lecz dziełem wieloletniej, sumiennej pracy, naznaczonej teologicznymi poszukiwaniami i przemyśleniami Ojca Profesora.

O ile łatwa jest ogólna, na wskroś pozytywna i pełna zachwytu ocena tej pozycji książkowej, o tyle trudniej jest szczegółowo wymienić wszystkie jej zalety, przede wszystkim ze względu na ogromne bogactwo merytoryczne. Niemniej jednak należy podkreślić bogaty, wielowątkowy charakter dzieła i przejawiającą się w nim zdrową otwartość 
na współczesne badania mariologiczne i nowe kierunki w mariologii. Ojciec Napiórkowski nie tylko wszechstronnie opisuje różne aspekty podejmowanych zagadnień, ale w sposób jasny i zdecydowany dochodzi do konkretnych wniosków, dając mocne wrażenie ich pewności. Nie należy to przecież do zadań łatwych, albowiem w dziejach mariologii pojawiło się wiele wątków, przynoszących wielość różnorakich opinii.

Dziękując ojcu Andrzejowi Napiórkowskiemu za tak wartościową pozycję książkową, należy mieć nadzieję, że zainteresują się nią nie tylko mariolodzy, lecz także ci, którzy swoje wysiłki naukowe realizują choćby na polu zgłębiania moralności inspirowanej Ewangelia (piszący te słowa jest teologiem moralistą). Każdy Czytelnik ma szansę znaleźć tutaj wiele materiału do teologicznej czy religijnej analizy i refleksji. Pod tym względem szczególnej wymowy nabiera ukazane w książce piękno życia Maryi, jej czystość i bezgrzeszność oraz służebna, macierzyńska rola wobec Boga - Człowieka i każdego człowieka. 